\title{
P300 em sujeitos com perda auditiva***
}

\author{
P300 in subjects with hearing loss
}

\author{
Ana Cláudia Mirândola Barbosa Reis* \\ Maria Cecília Martinelli Iório**
}

\section{*Fonoaudióloga. Doutora em Distúrbio da Comunicação Humana pela Universidade Federal de São Paulo - Escola Paulista de Medicina. Professora do Curso de Fonoaudiologia da Universidade de Franca. Endereço para correspondência: Rua Hercílio Batista Avelar, 889 Franca - SP - CEP 14403-096 (anacmbreis@yahoo.com.br). \\ **Fonoaudióloga. Doutora em Distúrbio da Comunicação Humana pela Universidade Federal de São Paulo - Escola Paulista de Medicina. Professora Adjunto do Departamento de Fonoaudiologia da pela Universidade Federal de São Paulo - Escola Paulista de Medicina.}

****Trabalho Realizado no Departamento de Otorrinolaringologia e Distúrbios da Comunicação Humana da Universidade Federal de São Paulo Escola Paulista de Medicina.

Artigo de Pesquisa

Artigo Submetido a Avaliação por Pares

Conflito de Interesse: não

Recebido em 08.07.2004.

Revisado em 11.09.2004; 10.03.2005; 16.05.2005; 04.07.2005; 11.04.2006; 17.05.2006; 29.06.2006.

Aceito para Publicação em 29.06.2006.

\begin{abstract}
Background: behavioral and electrophysiological evaluations contribute to the understanding of the hearing system and to the intervention process. Aim: to investigate the occurrence of P300 in subjects with congenital severe to profound hearing loss, according to the variables of gender, age and hearing loss level. Method: the design of this research is a descriptive transversal study. Twenty-nine subjects, 15 male and 14 female, ranging in age from 11 to 42 years, were evaluated. Inclusion criteria were: to have at least 11 years of age and no more than 45 years; to have the diagnosis of congenital severe to profound sensorineural hearing loss; to have no other disorder; and absence of central hearing loss or any other auditory conductive disorder. The first stage consisted of an auditory behavioral and physiological evaluation, including: pure tone audiometry (air and bone conduction measures), speech audiometry, SDT (Speech Detection Threshold) and functional gain measures for the subjects using hearing aids, and immittance measures - tympanometry and acoustic reflexes thresholds; transient evoked otoacoustic emissions (TEOAE); distortion product otoacoustic emissions (DPOAE). The electrophysiological evaluation was the fourth stage of the study and included: auditory brainstem response (ABR) and late latency response (P300). Results: P300 was obtained for 17 out of the 29 subjects. Mean latency and amplitude were $326.97 \mathrm{~ms}$ and $3.76 \mathrm{~V}$, respectively. A statistical significant difference was observed for latency when considering the variable age (electrode CzA2 p $<0.003$ and $\mathrm{CzA} 1 \mathrm{p}<0.02$ ) and for amplitude when considering the variable hearing loss level ( $\mathrm{p}<0.0015$ ). Conclusion: P300 can be recorded in subjects with hearing loss.
\end{abstract}

Key Words: Event- Related Potentials; P300; Evoked Potencial Auditory; Hearing Loss Sensorineural.

\section{Resumo}

Tema: as avaliações comportamentais e eletrofisiológicas contribuem para o entendimento do sistema auditivo e do processo de intervenção. Objetivo: estudar P300 em sujeitos com perda auditiva neurossensorial congênita, segundo as variáveis gênero, idade e grau da perda auditiva. Método: a presente investigação consiste em um estudo descritivo, transversal. Foram examinados 29 sujeitos, sendo 15 do gênero masculino e 14 do gênero feminino, com idade entre 11 a 42 anos. Os critérios de elegibilidade para composição da amostra foram: idade superior a 11 anos e inferior a 45 anos; ser portador de deficiência auditiva congênita severa ou profunda; não apresentar outro tipo de distúrbio; não apresentar perda auditiva central e/ou comprometimento condutivo. A primeira etapa caracterizou-se por avaliação comportamental auditiva e fisiológica que incluiu: audiometria tonal limiar (via aérea e via óssea), logoaudiometria - LDV e medidas do ganho funcional para os sujeitos que faziam uso de próteses auditivas, Imitanciometria: curva timpanométrica e pesquisa dos reflexos ipsi e contra-laterais, registro das emissões otoacústicas (EOA) - emissões otoacústicas transitórias (EOAT) e emissões otoacústicas por produto de distorção (EOAPD). A avaliação eletrofisiológica constituiu a quarta etapa do procedimento de coleta de dados e incluiu: potenciais auditivos evocados de tronco encefálico (PEATE) e de longa latência (P300). Resultados: o P300 foi registrado em 17 sujeitos, com latência e amplitude média de 326,97ms e 3,76V, respectivamente. Apresentou diferenças significantes da latência em relação à idade ( $\mathrm{p}<0,03$ para derivação CzA2 e p < 0,02 para derivação CzA1) e da amplitude, segundo o grau da perda auditiva (p < 0,0015). Conclusão: o P300 pode ser registrado em sujeitos com perda auditiva.

Palavras-Chave: Componente P300 de Potencial Evocado; Potencial Evocado P300; Potenciais Evocados Auditivos; Perda Auditiva Neurossensorial. 


\section{Introduction}

In the past few decades it has been evidenced an increase of publications regarding the study of the integrity of central auditory pathways through behavioral, electrophysiological and image evaluations, which seems coherent once most of the auditory system is central.

The association of objective and behavioral (subjective) methods of hearing evaluations has became more and more frequent for the professionals who deal with diagnostic, and for establishing more precisely the therapeutic follow up in cases of a hearing disorder diagnostic, specifically concerning the central and/or cognitive hearing disorders. The technological advance, the mastery of techniques, as well as the better knowledge of the clinical-diagnostic application and intervention are factors that have collaborated for the increasing associated use of these tests (Musiek \& Lee, 2001; Franco, 2001; Schochat, 2003).

There are a few studies in the literature that revise the registration of the long latency (P300) Auditory Evoked Potential (AEP) in subjects with hearing loss, and they are usually international publications.

P300 has been studied in order to evaluate the auditory function in different situations. Duarte et al. (2004) studied the cognitive auditory evoked potential (P300) in free field and verified that this procedure is viable and can contribute for the evaluation of subjects with hearing loss users of electronic devices and, consequently, for their rehabilitation processes.

The P300 is not elicited if the difference between rare and frequent stimuli is lower than the discrimination threshold (Hall, 1992). Nevertheless, the peripheral hearing loss may indirectly affect the latency of P3, as well as the latency of waves $\mathrm{N} 1$ and P2 is frequently modified (resulting in a modification of the P300) under hearing loss conditions.

For Musiek and Lee (2001), the P300 is not influenced by the hearing loss once the subject is able to realize the stimulus. Therefore, the peripheral hearing loss shouldn't impede the use of this measure. However, the P300 shows a great variability in the latency and amplitude intersubjects.

A possible use of the $\mathrm{P} 300$ is to monitor the therapy's effects, once a decrease of the latency occurs concomitant to an increase of the cognitive skill (Fjell and Walhovd, 2003). This enables that the P300 to be used in one of its most stable conditions, the intra-subjects measures. Studies in this area have been developed with children under a rehabilitation process, aiming at identifying the decrease of the P300 latency after an auditory training of subjects with auditory processing disorders (Kozlowski et al., 2004), of subjects with emotional disorders (Ibañez et al., 2000), children with ADHD - Attention Deficit Hyperactivity Disorder - (Schochat et al., 2002), with degenerative diseases such as Parkinson's disease (Pineroli et al., 2002), and children with learning difficulties (Farias et al., 2004).

Issues concerning the audiological diagnosis in school children with learning complaints have been discussed in Marchiori's (2002) and Santos \& Spinelli's (2003) studies. It can also be found in the literature a concern about reading and writing of the Deaf, being influenced by the hearing and the development of hearing perception (Balieiro, 2002).

The necessity to establish an evaluation and a follow up protocol associated to objective evaluations is present in the literature. Not only for subjects with hearing loss or attention deficits, but also for degenerative diseases allowing the data comparison with the progress of the disease regarding the speech, writing and hearing perception aspects (Jorge et al.; 2004).

Oates et al. (2002) reported that unpublished researches have systematically investigated the effects of the degree of the sensorineural hearing loss with the cortical AEP in a large number of individuals with hearing impairment. They consider that the sensorineural hearing loss has an impact in the time, in the durability and the localization of the basic cortical processes of detection and discrimination of the speech stimulus. This effect depends on the degree of the hearing loss, on the stimulus intensity and on the cerebral processing level.

Another significant data found by Oates et al. (2002) is that the degree of hearing loss affected the amplitudes and latencies of AEP components differently. The AEP amplitudes were considerably more variable than the AEP latencies for both groups, normal and with hearing loss. Furthermore, the threshold or the point where the hearing loss produced a change in the response was substantially greater for amplitudes in comparison to latencies.

According to the above authors, the association of the behavioral evaluation with the 
cortical AEP registers provides valuable information to audiologists regarding the several levels of cognitive processing that occur during the speech perception. The presence of N1 suggested physiological evidences of the speech stimulus arrival in the auditory cortex and demonstrated that the stimuli are heard by the individual. Recent evidences suggest that the presence of $\mathrm{N} 1$ could also indicate the arrival of information potentially discriminable by the auditory cortex. Nevertheless, this presence does not imply that the different stimulus is discriminated by the subject.

As the literature shows, many factors may "affect" the P300 results, specially the attention towards it (Colafêmina et al., 2000; Beynon et al., 2002).

Studies on the P300 amplitude related to gender and age have been described in the literature, although without a consensus. Concerning the latency, the literature reports that it increases with age and therefore it should be adjusted to the age when analyzing the test's results (McPherson, 1996; Oates et al., 2002, Jerger \& Lew, 2004).

Junqueira and Colafêmina (2002) found a mean value of $313,8 \mathrm{~ms}$ for the P300 latency.

Amplitude values require studies once the normality range reported by the literature is very broad, varying from 1,7 t 20 ?V. For Ruth and Lambert (1991), McPherson (1996) and Kraus and McGee (1999), the normality range for the P300 amplitude would be around 1,7 ?V to 19,0 ?V, and the latency between $220 \mathrm{~ms}$ to $380 \mathrm{~ms}$.

Thus, the purpose of this study was to investigate the Long Latency Auditory Evoked Potential, P300, in individuals with congenital hearing loss from severe to profound through the electrophysiological evaluation.

\section{Method}

The study was developed in the Speech and Hearing School-Clinic of University of Franca, São Paulo, from November 2001 to February 2003. The investigation consisted on a descriptive, transversal study.

Twenty nine subjects were examined, 15 male and 14 female, ranging in age from 11 to 42 years old.

The study project was approved by the Ethics Committee of the Federal University of São Paulo (CEP N ${ }^{\circ}$ 1011/01) and was started after the signing of the Informed Consent Term by the subject or a care taker.

The inclusion criteria for the study sample were: age over 11 years and below 45 years old; severe to profound congenital hearing loss; absence of other types of disorders; absence of central and/or conductive or mix hearing loss.

The study was developed in four stages. The First Stage was characterized by a documental retrospective research of each subject with hearing loss according to a pre-established protocol.

After the inclusion of the patient and with the consent of the care taker or the subject, the interview and the evaluation were carried out.

The Second Stage was performed with the subject when possible, or with the assistance of an interpreter if necessary, using a structured individual interview carried out in a room of the School-Clinic.

In the Third Stage, the Behavioral Hearing Evaluation was performed including the following tests: Tonal audiometry (air and bone conduction), Speech audiometry - SDT.

The physiological and electrophysiological evaluation constituted the Forth Stage of the Data Collecting process and included the following exams:

. acoustic Immitance: tympanometric curve and ipsi and contra-lateral acoustic reflex;

- otoacoustic Emissions (OEA): transient otoacoustic emission (TOAE) and distortion product otoacoustic emission (DPOAE). The OAE were tested in the subject's both ears. The equipment used was the ILO 292 - Otoacoustic Emission Analyzer (Otodynamics Ltda.), version 5.2, coupled to a conventional computer;

. brainstem Auditory Evoked Potential (BERA) and Long Latency Auditory Evoked Potential (LLAEP). In order to register these potentials, the equipment Biologic Systems Corp was used. The surface electrodes were placed on the forehead $(\mathrm{Fpz}=$ ground electrode), on the cranial vertex $(\mathrm{Cz}=$ active electrode), on the ears' lobes (reference electrodes: $\mathrm{A} 1=\mathrm{LE}$ and $\mathrm{A} 2=\mathrm{RE})$, phones $(\mathrm{TDH}-39)$.

The LLAEP (P300) was performed right after the BERA. The subject was still lying down and was asked to pay attention on the different stimuli (rare stimulus) that appeared randomly within a series of equal stimuli (frequent stimulus). The comprehension of the task was assured in order to avoid interferences on the results. Therefore, a specific day was scheduled for the subjects who needed an interpreter, and the comprehension of the procedure was guaranteed. Each participant was requested to respond with a motor activity, raising 
the index finger, and thus accuse the perception of the rare stimulus every time it appeared. Once the purpose of this evaluation was the identification of the P300, it is known that the modification of the response manner (instead of mentally counting, the subject should raise the index finger) does not interfere on the desired response.

Before the registration of the responses, the subject underwent the test as a training procedure and was told that the rare stimulus could take a long time to appear or appear in a short time interval. After the training the test and the registration started.

The following parameters were used to obtain the P300: low frequency binaural acoustic stimuli (tone burst with a $20 \mathrm{~ms}$ plateau and a $5 \mathrm{~ms}$ rise/fall) for the frequent stimulus ( $80 \%$ probability) and a higher one, rare stimulus ( $20 \%$ probability). The rare stimulus frequency and intensity, as well as the frequent one's, were selected base don the tonal audiometry, that is, frequencies with present thresholds. The stimulus intensity also varied according to the used frequency and the hearing threshold. The time analysis was $500 \mathrm{~ms}$, filter from 0,5 to $30 \mathrm{~Hz}$, sensibility of 160 ? $\mathrm{V}$, alternate polarity. The electrodes impedance was lower or equal to 5 kohms. 300 stimuli with no artifacts were used (approximately 240 frequent and 60 rare) in order to obtain the potentials. The triggering frequency or the presentation rate was one stimulus per second.

In order to determine the P300 and the components (N1, P2, N2) the criterion elaborated by Junqueira and Colafêmina (2002) was used.

The acoustic immitance, OAE and BERA procedures were not analyzed in this study once they were only used to assure the eligibility of the subjects.

Thus, the material used in the present study was composed by the P3 or P300 wave of the LLAEP. The complex N1, P2 and N2 was not analyzed once the physical characteristics of the stimuli were adequate to the subjects' needs, as described before. Once the stimuli detection by the subjects was assured, the complex N1, P2, N2 was present in the 29 studied subjects.
The statistical tests used in the comparison of the groups of this study were selected in order to adequate to each situation. In all independent groups, the normality test and the F test for the comparison of variances were performed, and for the correlated groups the correlation coefficients and the significance test were calculated. The statistical tests used are identified in each table. The significance level was 0,05 or $5 \%(\mathrm{p}<0,05)$.

\section{Results}

Initially, it was verified the presence of the component $\mathrm{P} 300$ of the LLAEP in the 29 evaluated subjects; results are presented in figure 1 .

Next, a comparative study of the P300 component according to the variables gender, age and degree of hearing loss was performed.

After obtaining the P300 latencies and amplitudes of each subject, the descriptive measures of latencies and amplitudes are presented in tables 2 and 3 , respectively.

Next, the results of the $\mathrm{P} 3$ component latency study are presented in tables 4, 5 and 6 according to the variables gender, age and degree of hearing loss.

No significant difference was observed between the average latency according to the variables gender and derivation CZA1 and CZA2 (Table 3), or when compared to the groups of hearing loss (severe and profound) (Table 7). Significant differences in the latencies were observed when the groups were contrasted regarding the age (Table 4).

The P300 amplitude study related to the derivation $\mathrm{CzA} 1$ and $\mathrm{CzA} 2$ according to the variables gender, age and degree of hearing loss is presented in tables 7,8 and 9, respectively.

No significant differences were observed between the average amplitude when compared to the gender (Table 6) and to the variable age (Table 7). It was observed a significant difference in the amplitude between the two groups according to the variable degree of hearing loss (Table 8). 
FIGURE 1. Percentage distribution according to the absence or presence of the component P3 $(\mathrm{N}=29)$.

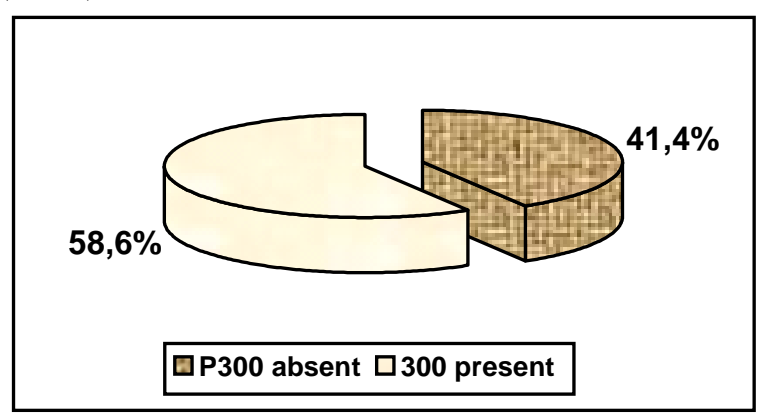

TABLE 1. Descriptive measures of latêncies (MS) of the component P3 according to CZA1 and CZA2

\begin{tabular}{lccc}
\hline \hline $\mathbf{N}$ & $\begin{array}{c}\text { Latencies (ms) } \\
\text { CzA1 }\end{array}$ & $\begin{array}{c}\text { Latencies (ms) } \\
\text { CzA2 }\end{array}$ & $\begin{array}{c}\text { Latencies (ms) } \\
\text { CzA1 and CzA2 }\end{array}$ \\
\hline \hline Average & 17 & 17 & 34 \\
\hline Median & 326,29 & 327,64 & $\mathbf{3 2 6 , 9 7}$ \\
\hline SD & 322,00 & 322,00 & 322,00 \\
\hline SE & 38,05 & 42,58 & 39,77 \\
\hline Minimum value & 9,23 & 10,33 & 6,82 \\
\hline Maximum value & 251,00 & 256,00 & 251,00 \\
\hline \hline
\end{tabular}

$\mathrm{N}=$ number of subjects $\quad \mathrm{SD}=$ Standard deviation $\quad \mathrm{SE}=$ standard error $\quad \mathrm{ms}=$ milliseconds $\mathrm{CZ} \mathrm{A} 2$ and $\mathrm{CZA} 1=$ derivation

TABLE 2. descriptive measures of amplitudes $(\mu \mathrm{V})$ of the component P3 according to CZA1 and CZA2

\begin{tabular}{|c|c|c|c|}
\hline & $\begin{array}{c}\text { Amplitudes ( } \mu v) \\
\text { CzA1 }\end{array}$ & $\begin{array}{c}\text { Amplitudes ( } \mu v) \\
\text { CzA2 } \\
\end{array}$ & $\begin{array}{l}\text { Amplitudes ( } \mu v) \\
\text { CzA1 and CzA2 } \\
\end{array}$ \\
\hline $\mathbf{N}$ & 17 & 17 & 34 \\
\hline Average & 3,85 & 3,66 & 3,76 \\
\hline Median & 3,05 & 2,75 & 3,03 \\
\hline SD & 1,93 & 2,55 & 2,24 \\
\hline SE & 0,47 & 0,62 & 0,38 \\
\hline Minimum value & 1,54 & 0,38 & 0,38 \\
\hline Maximum value & 8,36 & 9,63 & 9,63 \\
\hline $\begin{array}{ll}\mathrm{N}=\text { nun } \\
\end{array}$ & "SD = Stand & $\mathrm{SE}=\operatorname{stan}$ & " $\mu \mathrm{v}=$ microvolts \\
\hline
\end{tabular}

TABLE 3. Descriptive measures of latêncies (MS) of the component P3 according to the variable gênder

\begin{tabular}{|c|c|c|c|c|c|c|c|c|}
\hline & \multicolumn{4}{|c|}{ paired T student * } & \multicolumn{4}{|c|}{ " unpaired T student * } \\
\hline & \multicolumn{2}{|c|}{ Male } & \multicolumn{2}{|c|}{ Female } & \multicolumn{2}{|c|}{ CzA2 } & \multicolumn{2}{|c|}{ CzA1 } \\
\hline & $\mathbf{C z A 2}$ & CzA1 & CzA2 & CzA1 & $\mathbf{M}$ & $\mathbf{F}$ & $\mathbf{M}$ & $\mathbf{F}$ \\
\hline Average & 331,9 & 325,4 & 322,9 & 327,3 & 331,9 & 322,9 & 325,4 & 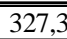 \\
\hline Median & 341,0 & 324,0 & 321,0 & 319,0 & 341,0 & 321,0 & 324,0 & 319,0 \\
\hline SD & 45,85 & 42,96 & 41,14 & 34,61 & 45,85 & 41,14 & 42,96 & 34,61 \\
\hline SE & 15,28 & 14,32 & 14,54 & 12,24 & 15,28 & 14,54 & 14,32 & 12,24 \\
\hline $\mathbf{P}$ & \multicolumn{2}{|c|}{0,45} & \multicolumn{2}{|c|}{0,61} & \multicolumn{2}{|c|}{0,68} & \multicolumn{2}{|c|}{0,90} \\
\hline
\end{tabular}

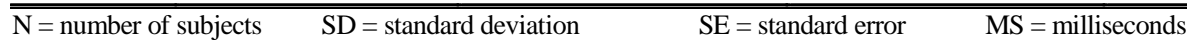

$\mathrm{CZ} \mathrm{A} 2$ and $\mathrm{CZA} 1=$ derivation $\mathrm{M}=$ male $\mathrm{F}=$ female $\quad * *$ statistical study used 
TABLE 4. Descriptive measures of latêncies (MS) of the component P3 according to the variable age (N=29)

\begin{tabular}{|c|c|c|c|c|c|c|c|c|}
\hline & \multicolumn{2}{|c|}{ paired T student* } & \multicolumn{2}{|c|}{$\begin{array}{c}\text { Wilcoxon non } \\
\text { parametric Test * }\end{array}$} & \multicolumn{2}{|c|}{$\begin{array}{l}\text { Mann Whitney non } \\
\text { parametric Test * }\end{array}$} & \multicolumn{2}{|c|}{$\begin{array}{c}\text { Mann Whitney non } \\
\text { parametric Test * }\end{array}$} \\
\hline & \multicolumn{2}{|c|}{ Group: 11-24 y. } & \multicolumn{2}{|c|}{ Group: $25-45$ y } & \multicolumn{2}{|c|}{ Electrode CzA2 } & \multicolumn{2}{|c|}{ Electrode CzA1 } \\
\hline & $\mathrm{CzA2}$ & CzA1 & CzA2 & CzA1 & G 11-24 & G25-45 & G $11-24$ & G25-45 \\
\hline Average & 318,3 & 318,1 & 371,3 & 364,3 & 318,3 & 371,3 & 318,1 & 364,3 \\
\hline Median & 316,0 & 312,0 & 372,0 & 357,0 & 316,0 & 372,0 & 312,0 & 357,0 \\
\hline SD & 40,97 & 36,18 & 11,02 & 20,98 & 40,97 & 11,02 & 36,18 & 20,98 \\
\hline SE & 10,95 & 9,67 & 6,36 & 12,12 & 10,95 & 6,36 & 9,67 & 12,12 \\
\hline $\mathbf{P}$ & \multicolumn{2}{|c|}{0,98} & \multicolumn{2}{|c|}{0,38} & \multicolumn{2}{|c|}{$\mathbf{0 , 0 3}$} & \multicolumn{2}{|c|}{$\mathbf{0 , 0 2}$} \\
\hline Imber of subjects & SD & $\operatorname{lard} d$ & & $S F=S$ & lerror & $\mathrm{S}=$ milli & nds & tatistical \\
\hline
\end{tabular}

TABLE 5. Descriptive measures of latêncies (MS) of the component P3 according to the variable degree of hearing loss (N=29) unpaired $T$ student $*$

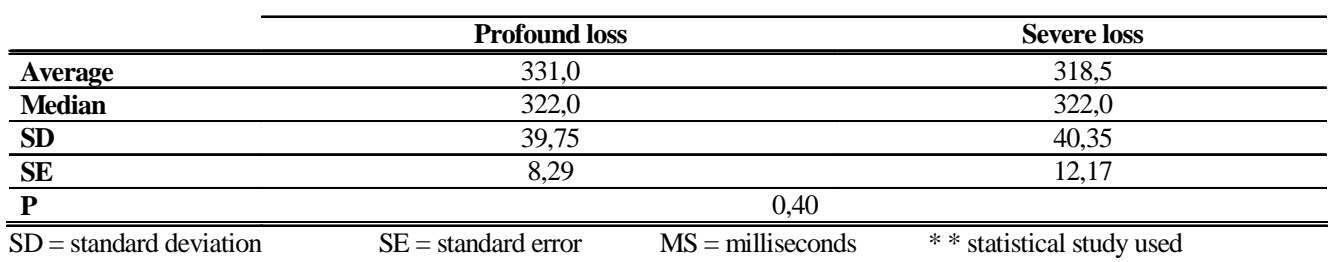

TABLE 6. Descriptive measures of amplitudes $(\mu \mathrm{V})$ of the component $\mathrm{p} 3$ according to the variable gênder

\begin{tabular}{|c|c|c|c|c|c|c|c|c|}
\hline & \multicolumn{4}{|c|}{ paired $T$ student * } & \multirow{2}{*}{\multicolumn{2}{|c|}{$\begin{array}{c}\begin{array}{c}\text { unpaired } T \text { student } \text { with } \\
\text { Welch correction * }\end{array} \\
\text { Electrode CzA2 } \\
\end{array}$}} & \multirow{2}{*}{\multicolumn{2}{|c|}{$\begin{array}{c}\text { paired } T \text { student * } \\
\text { Electrode CzA1 } \\
\end{array}$}} \\
\hline & \multicolumn{2}{|c|}{ Male } & \multicolumn{2}{|c|}{ Female } & & & & \\
\hline & CzA2 & CzA1 & $\mathrm{CzA2}$ & CzA1 & $\mathbf{M}$ & $\mathbf{F}$ & $\mathbf{M}$ & $\mathbf{F}$ \\
\hline Average & 4,45 & 4,35 & 2,77 & 3,29 & 4,45 & 2,77 & 4,35 & 3,29 \\
\hline Median & 3,18 & 3,22 & 2,60 & 2,93 & 3,18 & 2,60 & 3,22 & 2,93 \\
\hline SD & 3,14 & 2,34 & 1,40 & 1,26 & 3,14 & 1,40 & 2,34 & 1,26 \\
\hline SE & 1,05 & 0,78 & 0,50 & 0,45 & 1,05 & 0,50 & 0,78 & 0,45 \\
\hline $\mathbf{P}$ & \multicolumn{2}{|c|}{0,88} & \multicolumn{2}{|c|}{0,17} & \multicolumn{2}{|c|}{0,17} & \multicolumn{2}{|c|}{0,26} \\
\hline
\end{tabular}

TABLE 7. Descriptive measures of amplitudes $(\mu \mathrm{V})$ of the component $\mathrm{P} 3$ according to the variable age

\begin{tabular}{|c|c|c|c|c|c|c|c|c|}
\hline & \multicolumn{2}{|c|}{ paired $T$ student } & \multicolumn{2}{|c|}{$\begin{array}{c}\text { Wilcoxon non } \\
\text { parametric Test }\end{array}$} & \multicolumn{2}{|c|}{$\begin{array}{l}\text { Mann- Whitney non- } \\
\text { parametric Test }\end{array}$} & \multicolumn{2}{|c|}{$\begin{array}{l}\text { Mann- Whitney non- } \\
\text { parametric Test }\end{array}$} \\
\hline & \multicolumn{2}{|c|}{ Group: 11-24 y. } & \multicolumn{2}{|c|}{ Group: $25-45$ y } & \multicolumn{2}{|c|}{ Electrode CzA2 } & \multicolumn{2}{|c|}{ Electrode CzA1 } \\
\hline & $\mathrm{CzA2}$ & CzA1 & $\mathrm{CzA2}$ & CzA1 & G11-24 & G25-45 & G11-24 & G25-45 \\
\hline Average & 3,70 & 3,80 & 3,46 & 4,06 & 3,70 & 3,46 & 3,80 & 4,06 \\
\hline Median & 2,80 & 3,03 & 2,75 & 4,17 & 2,80 & 2,75 & 3,03 & 4,17 \\
\hline SD & 2,79 & 2,09 & 1,30 & 1,17 & 2,79 & 1,30 & 2,09 & 1,17 \\
\hline SE & 0,74 & 0,56 & 0,75 & 0,67 & 0,74 & 0,75 & 0,56 & 0,67 \\
\hline $\mathbf{p}$ & \multicolumn{2}{|c|}{0,84} & \multicolumn{2}{|c|}{0,13} & \multicolumn{2}{|c|}{0,33} & \multicolumn{2}{|c|}{0,33} \\
\hline
\end{tabular}

** statistical study used G 11-24 = group of 11 to 24 years G25-45= group of 25 to 45 years 
TABLE 8. Descriptive measures of amplitudes $(\mu \mathrm{V})$ of the component P3 according to the variable degree of hearing loss

\begin{tabular}{|c|c|c|}
\hline & \multicolumn{2}{|c|}{ unpaired $T$ student $*$} \\
\hline & Profound loss & Severe loss \\
\hline Average & 2,69 & 5,98 \\
\hline Median & 2,80 & 5,24 \\
\hline SD & 1,00 & 2,49 \\
\hline SE & 0,21 & 0,75 \\
\hline $\mathbf{P}$ & \multicolumn{2}{|c|}{0,0015} \\
\hline
\end{tabular}

\section{Discussion}

The subject age and gender are factors correlated to the electrophysiological evaluation results since the 70s. Authors have tried to relate this variable to the latency and amplitude found in the auditory evoked potential, of short, middle or long latency.

In this study, the $\mathrm{P} 3$ component of the long latency AEP (P300) was studied and, therefore, the discussion will always report to it.

The group studied was balanced regarding the variables involved, therefore the sample was constituted by 29 subjects, 15 male $(51,72 \%)$ and 14 female $(48,27 \%)$.

Concerning the subjects' age, the option for the age group from 11 to 45 years old was based on published studies with normal hearing subjects that showed a latency variation as a function of the age, with an increase of the latency after 25 years of age, which tends to be smaller in the period from 18 to 25 years of age (McPherson, 1996; Oates et al., 2002, Jerger \& Lew, 2004).

The cortical AEP associated to the behavioral evaluations may be used to evaluate the central auditory system (Ibañez et al., 2000; Schochat et al., 2002; Pineroli et al., 2002; Marchiori, 2002; Balieiro, 2002; Santos \& Spinelli, 2003; Fjell \& Walhovd, 2003; Kozlowski et al., 2004; Faria et al., 2004). This association of electrophysiological measures and behavioral evaluation produces a preview of the time, potential and location of the auditory processes in the cerebral cortex in relation to the hearing perception (Musiek, 1989; Franco, 2001; Oates et al., 2002; Schochat, 2003; Duarte et al., 2004; Jorge et al., 2004).

The P300 results of all subjects of this research were similar to the ones found in the literature regarding the appearance of $\mathrm{N} 1$, once the frequency and intensity were adjusted for each subject, as previously described.

As shown in figure 1, it was verified in this study that 17 of the 29 subjects presented the register of the P3 component $(58,6 \%)$ and 12 subjects $(41,4 \%)$ did not present the potential, in agreement with the studies of Hall (1992) and Oates et al. (2002).

There are many factors that can interfere in the long latency auditory evoked potential recording. In this study such factors were controlled during the whole data collecting period, as observed in the item procedures of the data collecting for the LLAEP, through the interview protocol. Therefore, the 12 subjects who did not present the P300 registers suggest the lack of the long latency potential triggering due to other reasons rather than the lack of sound detection or other factors not controlled in the research, known by the literature (Colafêmina et al., 2000; Beynon et al., 2002).

In this study, the average found for the P300 latency was $326,9 \mathrm{~ms}$, with a standard deviation of $39,7 \mathrm{~ms}$. These data are in agreement with the studies of Ruth and Lambert (1991), McPherson (1996) and Kraus and McGee (1999), where the latency found for normal individuals varied from $220 \mathrm{~ms}$ to $380 \mathrm{~ms}$, and with the study of Junqueira and Colafêmina (2002). The latencies of the component P3 obtained in this study in subjects with sensorineural severe to profound hearing loss demonstrated that there isn't an interference of the hearing loss on the latency of the $\mathrm{P} 3$ component.

The P300 latency, as well as the components N1 and P2 latencies were not altered in this study probably due to the parameter initially established, of presenting the rare and the frequent stimuli in perceptive intensities for the subjects.

The average found for the P300 amplitude (Table 2) was $3,76 ? \mathrm{~V}$, with a standard deviation of 2,24 ? V. The minimum and maximum values were 0,38 ?V and 9,63 ?V, respectively. The mean value found in this study is within the normality range considering the studies published by Ruth and Lambert (1991), McPherson (1996) and Kraus and McGee (1999), and only three of the 17 subjects who presented P300, presented amplitudes below the normality range. 
Oates et al. (2002) reported that the cortical AEP's amplitudes are related to the degree of hearing loss; this data corroborates the findings of this study. The same authors considered that the P300 amplitude of subjects with hearing loss was reduced for the late potentials (N2 and P300) and concluded that this finding was probably due to a smaller relation of cortical neurons that could actually contribute for the response.

Comparing the average of latencies (Table 3 ) and amplitudes (Table 6) of the subjects by gender, it was not observed a significant difference between the averages of these variables in the groups.

There isn't a consensus in the literature about the influence of the gender in the P300 latency and amplitude results.

Concerning the age, the data of the present study were compatible to the ones found in the literature (McPherson, 1996; Oates et al., 2002, Jerger \& Lew, 2004). When subjects of the same age were compared, no significant differences were observed in the latency between the derivations CzA2 and CzA1; but when the two groups of different ages were compared (11 to 24 years) and ( 25 to 45 years), significant differences were verified $(\mathrm{p}<0,03 \mathrm{e} \mathrm{p}<0,02)$ (Table 4).

For Hall (1992) and McPherson (1996), the morphological characteristics of the waves, as well as the latency and amplitude values reach maturity until the adolescence, and in general, children from five to seven years old present $\mathrm{P} 300$ with increased latencies and decreased amplitudes.

This last data, referring to the amplitude, was not found in the present study, that is, no significant differences were found in the amplitude regarding the age (Table 7).

The association of the results, presence or absence of $\mathrm{P} 300$, to the severe and profound degrees of hearing loss evidenced through the statistical study that it is significant when studied by ear (Table 8).

The data found in this study are in agreement with the ones from Musiek (1989) and Oates et al. (2202), who considered no interference of the peripheral hearing loss on the P300 measures, since the subject is able to hear the stimulus, as mentioned before.

The 29 subjects of this research heard the stimulus and were "trained" to respond to the test, therefore it was guaranteed not only that the stimulus could be detected but also that somewhere in the ANS it could be realized and discriminated in relation to the difference of frequencies. This could be observed by the presence of the complex N1P2N2 in the subjects. The question raised from these findings is: if the stimulus arrived, why didn't it trigger the P300 in 12 subjects?

Hall (1992) verified in his studies that the P300 is not elicited if the frequency difference for rare and frequent stimuli is lesser than the discrimination threshold.

Concerning the degree of hearing loss, it wasn't observed in this study significant difference between the mean latency of P300 of the two studied groups (severe and profound degrees) (Table 5).

It is worth to stress that Musiek (1989) called the attention for the fact that the P300 shows a great variability in the latency and amplitude inter-subject. Koozlowski et al. (2004) used the P300 in order to monitor the effects of the therapy in subjects with altered auditory nervous system, and it could be observed that the intra-subject measures is one of the most stable conditions of the P300.

Oates et al. (2002) reported that unpublished researches have systematically investigated the effects of the degree of sensorineural hearing loss in cortical AEP. The authors found that when the sensorineural hearing loss increases, there is a significant decrease of the amplitude and a prolonged latency for all AEP components, as well significant increase in the reaction time and an inefficient behavioral hearing discrimination performance.

The data found in the present study related to the amplitude and to the behavioral performance of the subjects agreed with studies presented by Oates et al. (2002). Comparing the amplitudes in the groups of subjects with severe and profound hearing loss, it was observed a significant difference in the mean amplitude between both studied groups $(\mathrm{p}=0,0015)$ (Table 8).

\section{Conclusions}

P300 can be recorded in subjects with congenital severe or profound sensorineural hearing loss.

The latencies of the wave P3 do not present differences when contrasted with gender and degree of hearing loss, and was greater in the age group from 25 to 45 years than in the age group from 11 to 24 years.

The amplitude measures of the wave P3 do not present differences when contrasted with gender and age. The P300 amplitude is greater in subjects with severe hearing loss than in subjects with profound hearing loss. 


\section{References}

BALIEIRO, C. R. A escrita na clínica fonoaudiológica e a pessoa surda: possível lugar de constituição do sujeito e da linguagem. R. Dist. Comun., São Paulo, v. 14, n. 1, p. 0925, dez. 2002.

BEYNON, A. J.; SNIK, A. F.; VAN DEN BROEK, P. Evaluation of cochlear implant benefit with auditory cortical evoked potentials. Int. J. Audiol., Hamilton, v. 41, n. 7, p. 429-435, oct. 2002.

COLAFÊMINA, J. F.; DE FELIPE, A. C. N.; JUNQUEIRA, C. A. O.; FRIZZO, A. C. F. Potenciais evocados auditivos de longa latência (P300) em adultos jovens saudáveis: um estudo normativo. R. Bras. Otorrinolaringol., São Paulo, v. 66 , n. 2, p. $144-148$, mar.-abr. 2000.

DUARTE, J. L.; AlvarenGA, K.de F.; COSTA, O.A. Potencial cognitivo p300 realizado em campo livre. Rev. Bras. Otorrinolaringol., São Paulo, v. 70, n.6, p. 781786, dez. 2004.

FARIAS, L. S.; TONIOLO, I. F.; CÓSER, P. L. P300: avaliação eletrofisiológica da audição em crianças sem e com repetência escolar. R. Bras. Otorrinolaringol., São Paulo, v. 70, n. 2, p. 194-199, mar.-abr. 2004.

FJELL, A. M.; WALHOVD, K. B. Effects of auditory stimulus intensity and hearing thresshold on the relationship among P300, age and cognitive function. Clin. Neurophysiol., Limerick, v. 114, n. 5, p. 799-807, may 2003.

FRANCO, G. M. The cognitive potential in normal adults. Arq. Neuropsiquiatr., São Paulo, v. 59, n. 2a, p. 198-200, june 2001.

HALL, J. Handbook of auditory evoked responses. Boston: Allyn \& Bacon, 1992.

IBAÑEZ, S.; BOBES, M.; VALDES, M.; MAROT, M. P300 en psiquiatria: transtornos atencionales en esquizofrenicos. R. Colomb. Psiquiatr., Bogota, v. 29, n. 3, p. 215-229, sept. 2000.

JERGER, J.; LEW, H. L. Principles and clinical applications of auditory evoked potentials in the geriatric population. Phys. Med. Rehabil. Clin. N. Am., Philadelphia, v. 15, n. 1, p. 235-250, fev. 2004.

JORGE, T. M.; LAMÔNICA, D. A. C.; CALDANA, M. de L. Doença de Parkinson: transtornos da comunicação oral e gráfica. R. Fono Atual, São Paulo, v. 7, n. 30, p. 14-25, $4^{\circ}$ trim. 2004.
JUNQUEIRA, C. A. O.; COLAFÊMINA, J. F. Investigação da estabilidade inter e intra-examinador na identificação do P300 auditivo: análise de erros. $R$. Bras. Otorrinolaringol., São Paulo, v. 68, n. 4, p. 468-478, jul.ago. 2002.

KRAUS, N.; McGEE, T. Potenciais auditivos de longa latência. In: KATZ, J. Tratado de audiologia clínica. São Paulo: Manole, 1999. p. 403-420.

KOZLOWSKI, L.; WIEMES, G. M. R.; MAGNI, C.; SILVA, A. L. G. da. A efetividade do treinamento auditivo na desordem do processamento auditivo central: estudo de caso. R. Bras. Otorrinolaringol., São Paulo, v. 68, n. 4, p. 427-432, maio-jun. 2004.

MARCHIORI, L. S. M. Análise das alterações auditivas em escolares com queixa de problemas de aprendizagem. R. Fono Atual, São Paulo, v. 5, n. 21, p. 10-15, $3^{\circ}$ trim. 2002.

McPHERSON, D. L. Late potentials of the auditory system. San Diego: Singular Publishing Group, 1996.

MUSIEK, F. E.; LEE, W. W. Potenciais auditivos de média e longa latência. In: MUSIEK, F. E.; RINTELMANN, W. F. Perspectivas atuais em avaliação auditiva. Trad. Gil D. 1. ed. bras. São Paulo: Manole, 2001. p. 239-267.

OATES, P. A.; KURTZBERG, D.; STAPELLS, D. R. Effects of sensorineural hearing loss on cortical event-related potential and behavioral measures of speech-sound processing. Ear Hear., Baltimore, v. 23, n. 5, p. 399-415, oct. 2002 .

PINEROLI, J. C. A.; CAMPOS, D. S. de; WIEMES, G. R. et al. Avaliação auditiva central com BERA e P300 na Doença de Parkinson. R. Bras. Otorrinolaringol., São Paulo, v. 68, n. 4, p. 462-466, jul.-ago. 2002.

RUTH, R. A.; LAMBERT, P. R. Auditory evoked potentials. Otolaryngol. Clin. North Am., Philadelphia, v. 24, n. 2, p. 349-370, apr. 1991.

SANTOS, F. A.; SPINELLI, M. A discriminação auditiva e o desempenho escolar. R. Dist. Comun., São Paulo, v. 14, n. 2, p. 309-318, jun. 2003.

SCHOCHAT, E.; SCHEUER, C. I.; ANDRADE, E. R. de. ABR and auditory P300 findings inchildren with ADHD. Arq. Neuropsiquiatr., São Paulo, v. 60, n. 3b, p. 742-747, sept. 2002.

SCHOCHAT, E. Resposta da latência média em crianças e adolescentes normo-ouvintes. Pró-Fono R. Atual. Cient., Barueri, v. 15, n. 1, p. 65-74, jan.-abr. 2003. 